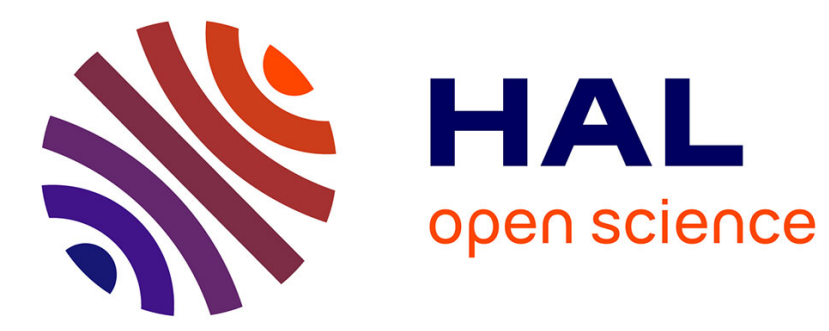

\title{
The legacy of positivism and the emergence of interpretive tradition in spatial planning
}

Simin Davoudi

\section{To cite this version:}

Simin Davoudi. The legacy of positivism and the emergence of interpretive tradition in spatial planning. Regional Studies, 2011, pp.1. 10.1080/00343404.2011.618120 . hal-00749640

\section{HAL Id: hal-00749640 \\ https://hal.science/hal-00749640}

Submitted on 8 Nov 2012

HAL is a multi-disciplinary open access archive for the deposit and dissemination of scientific research documents, whether they are published or not. The documents may come from teaching and research institutions in France or abroad, or from public or private research centers.
L'archive ouverte pluridisciplinaire HAL, est destinée au dépôt et à la diffusion de documents scientifiques de niveau recherche, publiés ou non, émanant des établissements d'enseignement et de recherche français ou étrangers, des laboratoires publics ou privés. 


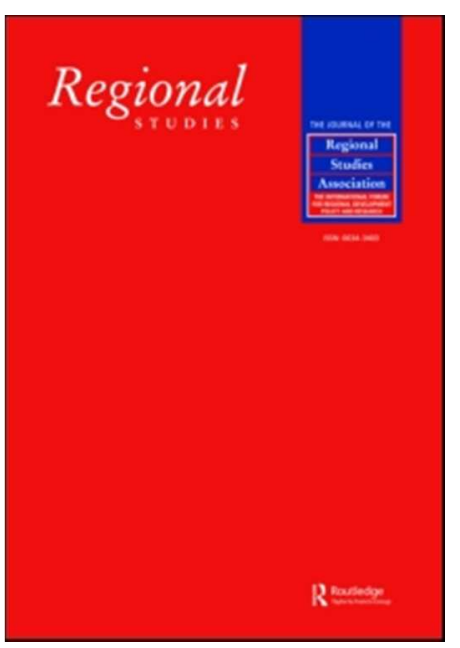

\section{The legacy of positivism and the emergence of interpretive tradition in spatial planning}

\begin{tabular}{|r|l|}
\hline Journal: & Regional Studies \\
\hline Manuscript ID: & CRES-2009-0273.R2 \\
\hline Manuscript Type: & Special Issue Paper \\
\hline JEL codes: & $\begin{array}{l}\text { P11 - Planning, Coordination, and Reform }<\text { P1 - Capitalist Systems < P - } \\
\text { Economic Systems, Q48 - Government Policy }<\text { Q4 - Energy }<\text { Q - } \\
\text { Agricultural and Natural Resource Economics, R52 - Land Use and Other } \\
\text { Regulations < R5 - Regional Government Analysis < R - Urban, Rural, } \\
\text { and Regional Economics }\end{array}$ \\
\hline Keywords: & $\begin{array}{l}\text { Positivist planning, interpretive planning, space and place, time and } \\
\text { future, evidence-based policy, scalar order }\end{array}$ \\
\hline \multicolumn{2}{|c}{} \\
\hline
\end{tabular}

SCHOLARONE ${ }^{\mathrm{m}}$

Manuscripts 
The legacy of positivism and the emergence of interpretive tradition in spatial planning

\author{
Simin Davoudi \\ Professor of Environmental Policy and Planning \\ School of Architecture, Planning and Landscape, Newcastle University \\ Claremont Tower, Newcastle upon Tyne, NE1 7RU, United Kingdom \\ simin.davoudi@ncl.ac.uk
}

\begin{abstract}
This paper draws on positivist and interpretive conceptualisation of space, place and time to present a framework for exploring how spatiality and temporality is articulated and represented in spatial planning. It focuses on five aspects of planning: conception of spatiality, spatial and scalar structuring, treatment of time and future, use of evidence in plan making, and representation and visualisation. How the two traditions have influenced planning, particularly in the UK, is discussed and illustrated by historical and contemporary examples. The paper concludes that while an interpretive approach is emerging in some areas of planning, positivism has retained its dominating influence.
\end{abstract}

Key words:

Positivist planning; interpretive planning; relational space; nested scale; time and future; cartographical representation; evidence-based policy

JEL codes: Z, Y, R 
1. Introduction

In the early 2000s, a major programme of reform was introduced by the British government which aimed to widen the scope of the planning system "beyond traditional land use planning" (ODPM, 2004a: 12), and towards what is known as 'spatial planning'. Spatial planning has been defined in different ways but often with reference to a type of planning which acts as a coordinator of other policy sectors and integrator of policy and investment priorities (Nadin, 2007). Whatever the definition, the spatial turn in planning was a belated response to the renewed enthusiasm for spatiality in other policy areas as well as in other disciplines. By the end of the millennium, there was a growing recognition that space and place mattered in the social and economic fortunes of localities (Amin and Thrift, 1995) and in the coordination strategies of governance. As Brenner (2000:373) suggests, "space is becoming a central object of political struggle in the contemporary world; it is no longer merely the 'medium' or 'theatre' of socio-political conflicts but one of their constitutive dimensions".

While the debate on the meaning of spatial planning is ongoing and the gap between rhetoric and reality remains wide, planners' attempt to implement it is undisputed. What is less clear is the type of spatiality that was conveyed by the emerging plans. Within the social sciences there are two distinct ways of conceptualising space and place: the positivist and the interpretive traditions. In section two the paper draws on these two perspectives to present a conceptual framework for exploring how spatiality is articulated, represented and visualised in planning. Emphasis is placed on five key aspects of planning: conception of spatiality, spatial and scalar structuring, treatment 
of time and future, use of evidence in plan making processes, and representation and visualisation. The ways in which the positivist and the interpretive traditions have influenced planning, particularly in the UK, will be discussed and illustrated by historical and contemporary examples. The paper concludes, in section three, that while some of the contemporary planning practices are moving towards an interpretive approach, positivism has remained highly influential in planning.

2. Positivist and interpretive traditions

Positivism refers to an empiricist approach to scientific knowledge which starts from the senses and particulars and gradually rises up to the most general axioms. It is based on Francis Bacon's second way of discovering truth, and rests on observation as the moment of truth when hypotheses are tested against the facts of the world. For empiricists, knowledge is a matter of bottom-up experience (a posteriori). This is what distinguishes them from rationalists for whom knowledge is a matter of topdown underlying theories and laws (a priori $)^{1}$. Both, however, belong to the naturalist tradition of enquiry. Both consider nature as independent, reason as unprejudiced, and a unitary scientific method as the appropriate way of explaining causal relations in both natural and social phenomena (Hollis, 2003). Within the social sciences, positivism refers to the approaches which apply scientific methods to human and social affairs; conceived as belonging to a natural order that is open to objective enquiry. Its most extreme version, the 1930s' Logical Positivism of the Vienna Circle, denied the existence of anything beyond observable experience. This extreme view was best captured in David Hume's assertion that there is a sharp distinction between "matters of fact" and "relations of ideas" (quoted in Hollis 2003:42). 
One of the most radical challenges to positivism has come from the interpretive or hermeneutics ${ }^{2}$ tradition which has offered an alternative to the naturalist view of the world; one which considers knowledge to be a matter of understanding rather than explanation. Social phenomena are seen as distinguishable from natural ones because they depend on the meaningful actions of individuals; they are intentional. This means that in the social domain instead of seeking to explain the causes of behaviour one is to seek the meaning of action (Hollis, 2003). Meaning refers to what is consciously and individually intended as well as what is commonly and often unintentionally significant. Within the social sciences the interpretive tradition has been associated with post-modernism and its objection to the grand narratives of social theories offered by naturalist approaches.

Whilst positivism has a long history in planning, the interpretive perspective is relatively new to it. For some commentators its emergence has raised questions about whether planning as a modernist project could operate in a postmodern time (Allmendinger, 1998). The following section will discuss how these two different perspectives lead to radically different conceptualisation of the five key aspects of planning mentioned above, and how these varying conceptualisations have shaped the evolving planning thoughts and practices, particularly in the UK. Historical and contemporary examples are drawn upon to illustrate the points made.

\subsection{Conception of spatiality}

Positivism portrays an absolute view of space which is rooted in Euclidean geometry. Euclid's three-dimensional geometry enjoyed uninterrupted sovereignty until it was 
challenged in the late $19^{\text {th }}$ century. His ideas were accepted for a long time because "it had been covertly built into Newtonian physics" (Scruton, 1996:361). The picture given by Isaac Newton was of space as an infinite container; "an entity in itself independent of whatever objects and events occupy it" (Agnew, 2005:83). For a positivist planning, space is a neutral container which can be understood through positivist science. Place is considered as objective, bounded, self-contained and measurable.

The interpretive tradition considers space as relational; a view which is often associated with Einstein's space-time concept (Agnew, 2005). However, the idea that space is relative and not absolute is far older and goes back to Leibnitz's philosophy. He suggested that, "spatial properties are relational, and the position of any object is to be given in terms of its relation to any other objects" (Scruton 1996:362). In the Leibnitzian view space is relational in the sense that it does not exist independent of objects and events and is constructed from the relations between them. It is dependent on the social and cultural processes and substances that make it up (Lefebvre, 1991). In the words of David Harvey (1996:53 original emphasis), "Processes do not operate in but actively construct space and time and in so doing define distinctive scales for their development".

An important feature of the distinction between the positivist and the interpretive approach to spatiality is the way in which they conceptualise place. The former considers space and place as either synonymous or binaries, while the latter understands them as dialectically related (Lefebvre, 1991; Harvey, 1989; Soja, 1989). The interpretive tradition, as manifested particularly in postmodern geography, 
attempts to expose the contingent nature of space and place and puts the emphasis on "fluidity, reflexivity, contingency, connectivity, multiplicity and polyvocality" (Davoudi \& Strange, 2009:37). Place is defined subjectively with people living not “in a framework of geometric relationships but a world of meaning' (Hubbard et al 2004). Space and place are seen as socially and culturally produced, or as Doreen Massey (2005: 61) puts it, as "simultaneity of multiple trajectories".

An early example of a positivist view of spatiality is the highly influential Charter of Athens (CoA, 1933). Published in 1933, it became a modernist manifesto for transformation of urban areas into functional cities. It was the brain child of a group of avant-garde architects and intellectuals who founded Congrès Internationaux d'Architecture Moderne (CIAM). Its portrayal of the city as the embodiment of four functions had a profound influence on the architecture and planning practices of postwar Europe and left its mark on numerous cities around the world (Davoudi \& Madanipour, 2012f). The 'CIAM city' (Dear, 1995) was to be built from scratch on a blank canvas and then filled with human activity. Le Corbusier (1929:232 original emphasis), the renowned exponent of CIAM principles, was of the view that "WE MUST BUILD ON A CLEAR SITE!" He advocated that, "The city of today is dying because it is not constructed geometrically". The solution would be offered by physical design. For example, "rational determination of street dimensions" was the solution for congestions; zoning and slum clearance was the solution for "irrational location" and overcrowding (CoA, 1933: no page number).

Like CIAM, the founding members of the planning movement in Britain were also looking for planning solutions to urban problems. They, however, were social 
visionaries rather than architects or planners. They considered planning as an 'art' rather than a 'science'. Nevertheless, like CIAM their urban solutions were physically-deterministic and utopian; and were considered to provide "a peaceful path to reform"3 . Ebenezer Howard's Garden City had to have a "fixed limit of ...32,000 people, living on 1,000 acres of land...It would be surrounded by a ... permanent green belt" (Hall 2002:93) which would neatly separate it from the surrounding countryside. When the Garden City reached its planned limit, another one would be started. This tightly-planned, neatly-structured and linearly-phased socio-spatial engineering project would then create a polycentric agglomeration which Howard called the Social City (Howard 1902). Contemporary spatial planning in the UK does not use a physically-deterministic language but, the spatiality of the plannedterritories is still constructed largely through quantification and factualisation. Quantitative indicators and physical attributes of the built and natural environment are often the dominant narratives that are drawn upon to signify a sense of place and a distinct place identity (see for example the Yorkshire and Humber Plan, 2006). What is less common is a social and cultural construction of spatiality around values, norms, beliefs, aspirations and memories.

A prominent feature of the 'spatial turn' in planning, and one which is particularly relevant to how spatiality is conceived, is its emphasis on distinctiveness in terms of both the distinctiveness of the localities and the distinctive approach to plan making ${ }^{4}$. The latter is frequently hampered by rigid, top-down procedural rules. In the interest of conformity these rules often squeeze out any attempts to originality. The former has been embraced as part of the plan making process. Local distinctiveness is seen as providing potential comparative advantage in an increasingly globalised world. Many 
local planning authorities have produced 'characterisation studies' of their localities as part of the evidential support for their plan making (DCLG, 2007). Typically, they present detailed descriptions of the physical aspects of the areas. A particularly elaborate example has been produced by London Borough of Barnet (Barnet, 2009). Its "overarching aim ... is to analyse and map the physical character of the Borough to inform the Council's planning policies" (ibid:4). It defines the meaning of "urban character" as "the individual aspects of a place that when combined ... make the place distinct from anywhere else" (ibid:8). It then emphasises that, "Factors that can influence and define place identity... typically include the following: Scale and grain; Land use; Network characteristics; Density; Street width; Building type, Height and massing; Architectural style; Vegetation, landscape and public realm treatment; and Topography" (ibid:8). The emphasis is clearly on physical attributes. The outcome portrays a 'distinct' character which is based on absolute and physical space, constructed by methods that are not dissimilar to the descriptive physical surveys of the traditional master plans. The social space and its cultural distinctiveness are reduced to a collection of statistical data on: car ownership, unemployment, index of deprivation and housing tenure (ibid).

An interpretive approach to planning complements these physical readings of space with social and cultural meanings. It combines the understanding of spatiality as 'matters of facts' with its understanding as 'matters of concern' (following Latour, 1993 \& 2005). This means paying attention to the objective and physical matters of space and place as well as the subjective and social concerns about space and place. Spatiality will then emerge, and continue to evolve, from the interrelationships between natural and physical characteristics, social expectations, cultural norms, 
power dynamics, and political bargaining. Spatiality would be subject to multiple interpretations and always in the process of being made. For the interpretive approach technical rationality of indicators and assessment methods are just one among multiple (and often competing) rationalities (Watson, 2003) which together shape a continuous process of becoming. Interpretive planners value the encounters between these (Healey, 2007) rather than shying away from the complexities that arise from them. Local distinctiveness is seen as a factor that evolves from such interactions as the plan making process unfolds.

\subsection{Spatial and scalar order}

A key feature of positivist planning is the aspiration to tame space and create order. This 'will to order' (Jensen and Richardson, 2004) has its origin in modernity and its eighteenth century Enlightenment project. It is based on the then dominant intellectual view of the world that considered universe as mechanically ordered, its parts susceptible to scientific discovery, and its malaise amenable to scientific solutions (Davoudi, 2012f); that science could conquer nature by discovering all its secrets, including those related to humanity (Hollis, 2002). Some commentators argue that this 'quest to control' relates to the real and perceived fears and anxieties about complexity and uncertainty (Schumaker, 1978). Yet, they add that, it not only circumvents politics and democracy, it may also mask the existence of the complexity itself. The desire to tame space has been inseparable from the search for "generating truth about the city" (Osbourne and Rose, 1999: 73), constructing 'spatial laws', and identifying spatial organising principles. Examples of the latter include: distancedecay effects, adjacency and proximity, and nested scalar hierarchies. As Foucault suggests, the demarcation of territory and the taming of space are part of 'planning 
technologies'. They are "the precise means by which [government] rationalities can be implemented in practice" (Murdoch, 2006:44).

In the interpretive planning the positivist tendencies of the 'will to order' would be replaced with the 'will to connect' (Hagens, 2010) multiple overlapping networks with continuous flows of people, resources and knowledges. Rather than controlling socio-spatial complexities, the emphasis would be on recognising them and seeking opportunities which may arise from them. An attitude of adventure would replace the attitude of fear (ibid). In interpretive planning spatial scales are not seen as hierarchical (global, national, local) but as "nodes in relational settings" where "the significance and composition of the relations defines the significance of scale" (Murdoch, 2006:21). Scale, like space, is conceived as socially constructed with contingent boundaries which are constantly territorialized and open to political contestation. While contemporary planning practices have begun to articulate the complex spatial and scalar relations through, for example, notions of network city or the use of 'fuzzy maps', as discussed below, they continue to be influenced by positivist principles. Three in particular have proved to be indispensible in planning and its quest for control. These are: spatial equilibrium, nested hierarchies and systems control, and will be elaborated in turn.

\subsubsection{Spatial equilibrium}

Among the early examples of the will to order space the Charter of Athens, mentioned above, is the most explicit one. It considered cities as being in a state of "chaos" because of "the uncontrolled and disorderly development of the Machine Age" (CoA, 1933, no page). It warned that the development of cities "suffers from absence of 
control" (ibid). Order and neatly classified and separated functions underpinned its urban solutions. CIAM's utopian vision of a 'good city' was one in which there was "a state of equilibrium among all its respective functions" (ibid). This was to be achieved by the power of plan as epitomised in Le Corbusier's dictum: 'The plan must rule' (1933:7). The quest for spatial equilibrium was later given an egalitarian dimension by the redistribution-based regional policy of the 1960s. Although the redistributive element of the balanced development policy has been increasingly undermined, its use as a spatial ordering principle has remained attractive. In contemporary plans the use of balanced development has in fact been heightened after the publication of the European Spatial Development Perspective (ESDP, 1999) and its promotion of polycentric development. The underlying assumption is that spatially-balanced (and ordered) territories are socially more equitable. While policy objectives such as 'spreading prosperity' (as in the Welsh Spatial Plan, 2004) or 'spreading urban-centred development opportunities' (as in the National Planning Framework for Scotland, 2004) may be considered as publically justified collective goals (Healey, 1997), the means by which they are to be achieved have remained physically deterministic and based on "stylised spatial options along a concentrationdispersal continuum" (Murray, 2009:129). Emphasis is put on: improving physical accessibility, developing complementary functions between geographically-proximate places, and privileging nearby relations over distant networks.

\subsubsection{Nested hierarchies}

The idea of ordering space through scalar hierarchies goes back to the 1930s' Christaller's Central Place Theory. This was a highly influential spatial organising principal which assumed that the complex dynamics of urban growth could be ordered 
in a nested hierarchy of settlements based on the uniform distribution of service centres in hexagonal arrangements. In some countries, such as Germany, the principle is still explicitly adopted in the spatial planning frameworks (BBR, 2001). In the UK, while Christaller is rarely mentioned in the plans, his idea of nested spatial hierarchy is frequently used to order spatial relations. The hierarchies are constructed through statistical analysis of functional interactions. The approach can potentially articulate the dynamics of the relational space but, its use in the contemporary plans is often highly instrumental aimed at sub-dividing space into smaller units and allocating predefined functions to each. The analyses are often based on reductionist measures, such as travel to work journeys, and relate to past and present functions. The outcome is used to designate some places as, for example, 'prime focus' for jobs, houses and services, others as 'local focus', and the rest as 'hinterlands'. Even less imaginatively, the planned-territories are sub-divided into: 'high', 'medium', and 'low growth' areas (as in Regional Development Strategy for Northern Ireland, 2001). The problem with this positivist approach is that firstly, the static nature of these spatial orders does not match the dynamic reality of the social and spatial interdependencies. Secondly, these allocations inevitably lead to some places gaining priority for future development and investment. However, the political nature of these allocations and their social implications are often masked by perceiving the process as a technical exercise.

An exception to this hierarchical approach in the contemporary planning practices is the articulation of the concept of network city and its associated terms such as hubs, gateways, nodes, etc. (see for example the Welsh Spatial Plan, 2004). The network city appears to have captured the relational understanding of space and offered a way of grappling with complex socio-spatial interactions. This is probably because the 
concept has double functions. On the one hand, it portrays relational complexities. On the other hand, it reconfigures these complexities into a more malleable form. Therefore, a "network city is simultaneously unpredictable and organized" (Beauregard, 2005:30). The concept allows planners to embrace complexity while at the same time avoiding its incapacitating tendencies. Notwithstanding these emerging relational understanding, physical geographies of proximity continue to be privileged over relational geographies of connectivity. This is particularly the case in terms of the limited attention given to the global positioning of the planned territory. Globalisation, when is mentioned, is often seen as benign; as a one-way force of change which the localities passively receive rather than actively shape (see for example the London Plan, 2004). The global socio-economic and political relations are often articulated by their association to physical infrastructure. Thus, territories are presented as, for example, 'a strategic transport cross-road', or 'on an axis', or 'as global gateway', or 'remote' (see for example the Yorkshire and Humber Plan, 2006). Other economic, social and cultural ties hardly feature in plans. Neither do plans convey the implications of these global positioning for their localities. Globalisation is portrayed only as matters of facts and not as matters of concern.

\subsubsection{Systems control}

The introduction of the systems theory was the heyday of positivism in planning and a response to the search for 'spatial laws'. Derived from the science of cybernetics ${ }^{5}$ and imported into planning through the work of Brian McLoughlin and George Chadwick in the late 1960 s, systems theory conceptualised cities as complex systems whose parts could be unpicked and then monitored and controlled by planners. Spatial planning was considered to be a form of systems analysis and control (Taylor 
1998:62). Assisted by the quantitative revolution of the time (Barnes 2001), an engineering-based spatial science emerged which aimed to develop spatial interaction models capable of measuring and predicting patterns of spatial change (Haggett, 1965). Planners were urged to move away from the descriptive physical surveys of the earlier master plans and develop general hypothesis about spatial distributions that could then be tested against the reality (Magee, 1973); the very essence of Popperian scientific method. An early example of a rigorous attempt to develop a "science of human settlement” is Doxiadis' 'Ekistics theory' (Doxiadis, 1968:317). For him, as for systems theorists, regular patterns were deemed to exist in the relationships between objects which could be mapped, modelled, and used as the basis for predicting future patterns. The complexity of "human settlements" was reduced to a series of "orderly classifications" of size, location and function (ibid: 31-35). As a result, and despite its name, his 'ideal Dynapolis' (the growing dynamic city) was prescribed to be "uni-directional" and "built on the basis of a rectangular grid network of roads" (ibid:365).

The application of the systems approach through spatial interaction models spread across the western world. In the UK it became the hallmark of sub-regional studies in the 1960 s and the 1970s. Sophisticated computer modelling techniques were used to generate policy choices for the fast-growing metropolitan areas. While the systems approach had developed partly in response to earlier criticisms of physical master planning, the systems view itself was confronted with similar criticisms. It was argued that many of the 'system' plans, including the structure plans of the 1970s which were supported by detailed 'reports of survey', had "a distinctly blueprint hint" (Faludi, 1973:146); that they were entrenched in the same 'fixities' that they were trying to 
avoid. It became clear that the perceived scientific objectivity could not be applied to socio-spatial systems irrespective of how sophisticated the methods or the models were, as admitted by Britton Harris, one of the most celebrated of all systems planners (Hall, 2002).

The following decades saw a diminishing emphasis on lengthy and detailed data collection and an undermining of systems theory. However, since the late 1990s and with the growing concerns about climate change, the systems approach and its engineering-based spatial science has been given an increasingly prominent place in planning (see Davoudi, 2012f). Planners are encouraged to use modelling and quantitative spatial analyses as the basis for determining 'climate proof' urban forms (ODPM, 2004b). As Michael Batty points out, planners have begun to talk about "a science of cities" again (Planning, 2009:23). This implies that positivist approaches are gaining a renewed influence in shaping planners' conception of spatiality. These technically 'conceived spaces' (Lefebvre, 1991:38) may serve a useful analytical and administrative purpose but, does little for creating a sense of place with which people can identify. Too much emphasis on 'conceived spaces' of planners and systems analysts would undermine the attempts to incorporate 'lived spaces' of imagination and 'perceived spaces' of daily routines (ibid). The latter refers to people's everyday life experiences of engaging in and with space.

Mirroring Lefebvre's 'trialectic of spatiality ${ }^{6}$, interpretive planning considers space as analytically conceived, physically lived, and culturally perceived. For interpretive planning the normative dimension lies in shifting the balance away from the abstract 'conceived space' to embrace the imaginative 'lived space' as a mechanism for 
enhancing its potential in re-orienting the 'perceived space' of everyday life (Davoudi \& Strange, 2009:38). This means drawing not just on the technical, but also the social and cultural spatial imaginations for understanding spatiality. An example of the attempts to move away from the physical arrangement of land uses and functions (things) in space towards capturing spatial patterns of social interactions (but not the embodied routine as suggested by Lefebvre) is the increasing use of the concept of functional urban regions or city regions which has seen an upsurge in planning in recent years. While this has enhanced the relational understanding of spatial interactions, its focus has been limited to economic interactions. The difficulties of quantifying and mapping social and cultural relations have led to their marginalisation in plan making processes, as mentioned above.

\subsection{Time and future}

One of the most profound legacies of positivism in spatial planning is the treatment of time and future. The ability to conceptualise time is the outcome of a long evolutionary path. As societies have grown in complexity, their temporal concepts have become more abstract. The abstract time is seen as a linear time running from past to future. Like the abstract space, time is seen as separate from its content and from action; it is considered as a quantifiable entity. The concept of the future refers to a dimension which is separate from the present and distinct from the past (Leccardi, 2008). In the positivist planning future is controllable and can be planned. The will to order space is coupled with the desire to control the future.

The idea that future can be planned also has its roots in the Enlightenment project (Luhmann, 1982) and its aspiration to free the future from the constraints of divinity 
and nature and make it subject to human domination. The future is considered as an 'open future' (Leccardi, 2008) capable of being controlled through human choices and decisions that are made at present. Planning movement in Britain was heavily influenced by the optimism and utopianism of such modernist ideas and their linear conception of history as progress and the ability of the Reason to guide it (Madanipour, 1995:22). Planning of time is indeed an antidote to the uncertainties generated by the future and a perceived insurance against its contingencies; it is the desire to bridge the gap between what happens and what can be done (Bauman, 1995). The positivist view of linear time with a precise beginning and a fixed end is still dominant in the contemporary plans. It is reflected in metaphoric expressions such as "a direction of travel" (as in the Welsh Spatial Plan, 2004), and in rhetorical questions such as "where will we live, where will we work"? (as in the Regional Development Strategy for Northern Ireland, 2001) The time frame is pitched at two decades or so and like the boundaries of the planned areas remains fixed. Ordering time, therefore, is as much a feature of positivist planning as is ordering space. As with spatial organising principles, planners draw on temporal organising concepts such as phasing and programming to tame the time. These temporal toolkits are added to planners' spatial toolkits to make up the 'planning technologies'. Quantitative forecasting of past trends is used to reduce future uncertainties. However, despite the efforts made to refine the methods even the most carefully calculated projections, such as housing need, tend to be challenged and revised several times during and after the plan preparation and not always because of access to better data or improved methods. In such a state of flux, it appears that "planning is condemned to solve yesterday's problems" (Tayler, 2005:157). None of this is to suggest that planners should abandon quantitative projections and forecasts. It is rather to highlight the 
limitations of positivist planning and its over-confidence in planners' ability to control the future.

For the interpretive planning, time is neither a biological nor a metaphysical given (Elias, 1992); it is, instead, socially constructed and differs for different generations and societies. For example, in the pre-industrial era the rhythm of nature and the succession of seasons constructed time. Interpretive planning acknowledges the existence of multiple times ranging from the rhythm of everyday life to the dynamics of glacial changes. Time is seen as cyclical, with past, present and future being interlinked. Interpretive planning acknowledges both the 'trialectic of spatiality', suggested by Lefebvre, and what I call the trialectic of temporality. It attempts to enhance the connection not only between intellectually conceived, physically lived and culturally perceived spaces, but also between past memories, present experiences and future expectations.

In describing what would be an "appropriate time and space of non-Euclidian form of planning", Friedmann (1993:482) suggests that, "the time of such planning is the real time of everyday events rather than imagined future time", because "it is only in the evanescent and still undecided present that planners can hope to be effective". However, he then adds that planners' concern with everyday does not mean the abandoning of concerns with an imagined future. Yet, for the interpretive planning the notion of future time is characterised through the recognition of future uncertainty, with action taking place in unexpected ways into unknown and disordered futures. Unlike the modernist meaning of the future as open and subject to control, the interpretive approach defines the future in terms of uncertainty and contingency. The 
image of the future as controllable is replaced with its image as indeterminate and indeterminable, riddled with unforeseeable possibilities as well as unpredictable risks. However, rather than putting too much emphasis on reducing uncertainties, the focus is on identifying potential opportunities. This requires a shift in attitude away from the fear of unknown and the recourse to conformity, towards the exploration of unknown and the search for novelty. Following Unger (2007), in the interpretive planning the recognition of the ubiquity of change and its potential for novelty and surprise characterises the concept of future time.

Positivist techniques of quantitative forecasting and projections would be complemented with qualitative foresights and scenario building. While the latter has been employed in plan making processes in recent years, the practice has not been widespread. This is reflected in a government's commissioned study which calls for “more future-oriented 'scenario' work telling local authorities what is possible, as well as what is already present" (DCLG, 2007:7). Furthermore, the emphasis has remained on fast-forwarding the selected present (Murray, 2009). Therefore, the imagined future is often not a set of possible and contingent futures capable of unfolding in multiple ways, but a certain and known future whose challenges can be anticipated and responded to by present decisions and actions. Yet, as Beauregard (1996:192) argues, "the text of a postmodern planner, in fact, should be consciously fragmented and contingent, non linear, without aspiration to comprehensiveness, singularity or even compelling authority". 


\subsection{The planning process and the use of 'evidence'}

Positivism considers planning as a rational decision making process in which valuefree experts rely on evidence to solve well defined and neatly structured planning problems. Evidence is understood as synonymous with facts, and credible evidence is interpreted as quantitative, measurable, and capable of establishing a clear cause and effect relations through scientific methods. The process is seen as linear in which the data collection and analysis un-problematically lead to planning and formulation of policy solutions. Although this approach reached its height in the rational planning of the 1960s and 1970s, some of its characteristics can be traced back to an earlier time. This is when the desire to order space became entwined with "generating truths about the city" by employing "mundane techniques of gathering, organising, classification and publication" (Osbourne and Rose 1999:73). A pioneering example is Patrick Geddes's famous dictum of: 'Survey before Plan'. Although it was assumed that "the survey naturally leads to the plan" (Abercrombie 1933:132) - much as it is now assumed that the evidence naturally leads to policy- in practice a creative leap was taken from the analysis of the survey to the making of plan. In other words, positivist methodology was combined with rationalist intuitions, or rather with simplistic aesthetic assumptions about urban form and layout (Taylor, 1998); an approach which was criticised by Jane Jacobs as "the pseudo-science of city planning and its companion, the art of civic design" (Jacobs 1961:16).

In the 1960 s and with the rise of scientism in planning the creative leap was squeezed out of the process in favour of further objectivity, which was to be achieved by applying scientific methods not only to spatial analysis in the plan, but also to the plan making itself (Taylor, 1998). The change marked the birth of the rational planning 
process which considered decision making as a cycle of logical steps. The physical survey of the earlier time was extended to include the collection of socio-economic data in detailed 'Reports of Survey' which were to provide the evidence-base or reasoned-justification (as was then known) for the plans' policies. The rational planning model has had a pervasive influence on planning and on policy making in general. Its assumptions have been carried through in the instrumental approach to evidence-based planning ${ }^{7}$ (see Cabinet Office, 1999a). Both underestimate the 'disjointed' and 'incremental' nature of the real world decision making (Lindblom, 1959) and the mismatch between "how the policy process should work and its actual messy, uncertain, unstable and essentially political realities' (Young et al 2002: 218). The emphasis on evidence-based planning was founded on the argument that, prior to the 2004 planning reform ${ }^{8}$, "the preparation of local plans has undervalued an understanding of spatial development patterns and trends, and the generation of strategic options that might flow from that understanding" (DCLG, 2007). To change the practice, planners have been urged to "gather evidence about their area ... at the earliest stage in the preparation of the development plan" (ODPM, 2004a:32); a process called 'front-loading'. Plans are, therefore, considered 'sound' if they "are founded on a robust and credible evidence base" (ibid:39-40). If they fail this "test of soundness', which is conducted by an independent panel, they will be taken back to the drawing board to be supported by "better evidence and reasoning" (ibid). While the attempts to provide better grounding for planning policies is justified, the underlying assumptions of the evidence-based planning are flawed. Indeed, the chosen terminologies are indicative of the enduring legacy of positivism in planning which considers an instrumental place for evidence in planning process. Its ethos is Popperian, portraying an epistemic view of knowledge which claims that, "one has 
knowledge only when one has a true belief based on very strong evidence" (Audi, 1996:252). Notions such as 'front-loading' are symptomatic of conceiving plan making as a linear process in which evidence for well-defined planning problems or goals are gathered first before planning solutions are formulated. It mirrors the positivist assumptions about the linear process of plan making in which "the collection of evidence takes place in self-contained, pre-production stage of plan making"; as one reading of the UK national policy would suggest (DCLG, 2007:5). However, despite the rhetoric of evidence-based policy, the way evidence is used in planning is inseparable from the social and political processes in which planners are engaged. As Hoch (1994:105) suggests: "Planners do not uncover facts like geologists do, but rather, like lawyers, they organise facts as evidence within different arguments ... all engage in persuasive rational arguments ... focused and attached to value objectives".

Interpretive planning does not consider evidence as the only contender in the making of planning policies. It stresses that often practical, institutional, ideological and political factors play a major part. Indeed, these factors may lead to what Carol Weiss (1975) calls the "problem of little effect", referring to a great deal of research that tends to sit on the shelf unnoticed. An audit of the UK government departments has shown the patchy role that evidence plays in day-to-day policymaking. It concludes that "little of the research commissioned by departments or other academic research was used by policy-makers." (Cabinet Office, 1999b: 36)

In the interpretive approach, planning process is seen as iterative rather than linear. Emphasis is placed on exploring shared notions of place and common understanding 
of space through discursive deliberations (Innes, 1996). Interpretive planning considers places as created through imaginative visioning, learning and storytelling (Sandercock, 2003). Methods such as these are seen as a way of expressing identity and belonging. Interpretive planning advocates that in order to understand a specific spatial practice, its historical emergence needs to be reconstructed and situated in the complex web of social and political life. The professional knowledge of planners would be one set of knowledge resources nestling amongst others. Such multiple sources of knowledge emerge from objective analysis as well as subjective experiences. In the interpretive planning, knowledge is seen as explicit and systematised as well as tacit and non-codified with no sharp distinction between 'expert' and 'lay' knowledge. Evidence, or indeed the ensemble of different knowledges, would play an enlightening rather than determining role in the process of plan making. Policy is considered to be informed by rather than based on evidence. Furthermore, the emphasis would be on evidence as contributing to wider public debate rather than merely the narrow domain of policy. Emphasis would, therefore, be on evidence-informed society (Davoudi, 2006: 22 emphasis added, following Smith, 1996).

There are already signs of this broader view of knowledge in the contemporary plan making practices in the UK. A notable example is how the evidence-based approach to planning has actually been interpreted by planners. The findings from a study commissioned by the UK government on the post-2004 planning practice shows that there is a "tendency for different types of material to be included in the meaning of 'evidence'. For instance many (planners) referred to the responses from community involvement and stakeholder events as "evidence"” (DCLG, 2007:5). It then adds that 
"it is entirely appropriate to use this type of material in developing, evaluating and justifying choices that are made, and it does represent an important source of information representing views of those individuals and organisations" (ibid). The report also shows the existence of "a wide range of collaborative activity to gather and interpret evidence" (ibid). Some of the concerns raised by the report are, however, similar to the criticisms of the perceived gap between 'survey' and 'plan' in Geddesian teaching. For example, the report states that "while many ... authorities have been able to demonstrate that appropriate evidence is being used...the rationale for the choices made may not be entirely clear..." (DCLG, 2007:5). From a positivist point of view this may be considered as a shortcoming in the objectivity of the decision making processes. From an interpretive point of view, however, the perceived gap indicates the limitations of the rational perspective itself on the decision making processes. The seemingly opaque nature of the link between evidence and options may well be due to the influence of the cognitive, social and institutional environment in which decisions, or more precisely practical judgments, are made. It would be unrealistic (and undesirable) to think that such influences can be removed from the process by employing more 'objective' methods.

In addition to the emergence of a broader meaning of evidence, contemporary planning practice also shows awareness of the iterative nature of the plan making processes. Contrary to the notion of 'front loading' which implies a recognisable moment (the front) in the process being filled in (loaded) by evidence, there seems to be a widespread recognition that "the use of evidence is an integral and ongoing part of preparing a local development framework" and that "evidence gathering is not a self-contained stage" (DCLG, 2007:19). The government's commissioned study (ibid) 
shows that planners' approach to what counts as legitimate sources of knowledge and how evidence is used in planning is much broader than what is centrally prescribed. However, it also shows that the range of evidence used in the planning process has remained limited. These mainly cover "standard topic studies dealing with ... housing, employment and retail" (ibid: 7). "Studies on wider quality-of-life themes such as culture, green space and health are rarely conducted" (ibid: 5). The problem with the dominance of topic-based technical information is that it can perpetuate the understanding of space as 'matters of fact' (such as housing and employment numbers) and sideline its understanding as 'matters of concern' (such as concerns about place-quality and lived spaces of everyday life). As mentioned earlier, such matters of concern do not feature in the 'characterisation studies', either.

\subsection{Representation and Visualisation}

"All forms of representation are abstraction from reality which bring some aspects forward to the attention and leave some in background or eliminate them completely" (Peattie, 1987:112).

The term representation differs from a positivist understanding of visualisation as a communication system. It emphasises the interdependence between "the symbolic structure that frame what is being said, written and shown during planning processes and the political structures that frame interactions during those processes" (Fischler, 1995: 23). While acknowledging the significance of the plan's text, metaphors and concepts in spatial representations, the main emphasis here is on the visual aspects of representation in the form of cartographical maps. 
The most dominant form of representing and visualising spatiality in positivist planning is static, Cartesian maps (Duhr, 2007). As Joyce (2003:52) suggests, the introduction of the Ordnance Survey maps in the $18^{\text {th }}$ century- (initially for military purposes) led to new ways of visualising cities on a "microscopic scale" and from the "omniscient view of the surveyor". It resulted in displaying land uses and data on skilfully crafted two-dimensional maps. Cartesian maps have remained a major part of spatial representations in the contemporary plans. In Latourian terms they continue to serve "as an immutable mobile"; as inscription that translate space into diagrammatic form, thereby reducing spatial relations to a single sheet of paper" (Murdoch 2006:134). Furthermore, in the process of making the city 'legible' by clear delineation a particular spatial image emerges which "hold some things constant (notably, buildings and streets) and remove others from view (notably, the movement and fluidity of urban social interactions)" (ibid). The fixed lines and colours of the map becomes the dominant spatial imaginary. For positivist planning, map-making, like other aspects of plan making, is seen as "scientific and untainted by social factors” (Harley 1992: 234). For the interpretive planning, maps have 'agency'. They serve as a powerful mechanism for including or excluding not only matters of concern, but also matters of fact. Cartography follows not just technical, but also social and cultural rules that govern the production of maps. As Harley suggests, "all maps are rhetorical" (ibid: 242) and work "in society as a form of power-knowledge" (ibid: 243).

In contemporary plans, while some maps continue to depict a positivist view of space as absolute and fixed, a new practice has emerged which uses what may be called 'fuzzy maps'. Instead of the geometric accuracy of traditional maps which depict 
spatiality as a mosaic of land uses, criss-crossed with roads and rail lines, the fuzzy maps blur the administrative and physical boundaries to represent ambiguous 'soft spaces' (Allmendinger \& Haughton, 2009). Although the boundaries are blurred, the extent of soft spaces is determined through the analyses that are based on quantitatively-identified functional reach of the 'core' cities. Fuzzy maps have been tactically used in several spatial strategies of the early 2000s to create new scales of working which do not necessarily match the hierarchical scales of the UK's formal planning system. As such, they have provided a way of visualising a dynamic and relational understanding of space. It is argued that the emergent of these new "soft spaces" has helped planners to break "away from the rigidities associated with the formal scales of statutory plan-making. (ibid:619) and represent the multi-scalar and overlapping geography of spatial relations. Besides scenario building, fuzzy maps can provide a useful way of representing and visualising networks and showing the untidy and complicated flows. However, like other forms of representations they inherently simplify reality and by doing that they amplify some aspects and marginalise others. As James Scott (1998:303) points out, such "simplifications...strip down reality to the bare bones so that the rules will in fact explain more of the situation". Like traditional maps, fuzzy maps also have agency and "fuse polity and territory" (Harley, 1988: 281). The ambiguity of fuzzy boundaries can, for example, can be tactically used to depoliticise the potential inter-administrative political tensions as fuzzy maps appear to be more schematic and suggestive than precise and prescriptive. 
3. Summary and conclusion

The legacy of Euclid, reinforced by a Newtonian view of spatiality, dominated planning ideas and practices in the UK in the first half of the twentieth century. It conceptualised space as an absolute, empty vessel filled with activities and objects. It treated place as objective, bounded and scientifically measurable. Seen in this way, space, scale, and time were to be ordered to create neatly separated categories, represented on two-dimensional, Cartesian maps to perform the conceived spaces of planners. The process was seen as linear and rational in which technical evidence, produced by experts, had an instrumental place.

Much has been written about the intellectual shortcomings and the practical limitations of the positivist approach to planning. The most radical critique has come from the interpretive tradition which conceptualises space as relational and dependent on the social and cultural process and substances that produce it. Place, in this approach, is defined subjectively by people's daily experience of engaging with it; by the perceived spaces of everyday life. Understanding of spatiality as matters of fact is combined with its understanding as matters of concern. Fluidity, contingency, dynamism and simultaneity are key characteristics of the interpretive planning. The desire to connect, rather than to control, spaces and times is what drives interpretive planners. The purpose of the interpretive planning is then two-fold. Firstly, to draw on intellectually conceived and culturally perceived spaces to shape physically lived spaces. Secondly, to draw on past memories and present experiences to shape future expectations. Acknowledging the complexities, uncertainties and contingencies of 
these connections, the emphasis of interpretive planning is not on reducing these but on seeking opportunities and expanding the space for novelty and adventure.

The discussion presented in this paper shows that although positivism has retained its powerful influence on planners' conception of spatiality, an interpretive approach has emerged in some aspects of contemporary planning practices in the UK. This is manifested in for example: the network city approach to spatial relations which challenges the traditional hierarchical way of organising space and scale; the attempts to challenge the fixed administrative boundaries by focusing on functional interrelationships; the use of fuzzy maps to visualise the un-bounded nature of flows; the articulation of uncertainties and contingencies through qualitative scenario buildings; and, the use of experiential knowledge in plan making processes in a nonlinear way. However, these developments are taking place in parallel with pressures which tend to strengthen positivism in planning. The rhetoric of evidence-based policy is one such pressure. Although it has been interpreted in much broader way than was intended initially, it continues to push planning practices towards the outdated technical rational approaches of the mid-twentieth century. Another pressure comes from the rise of systems approach in planning with a claim to reduce the uncertainties in climate change and its impacts.

The exploratory nature of the discussion presented in this paper does not lend itself to a decisive conclusion. However, it is possible to speculate that the interpretive approach will find it difficult to offer planners alternative ways of articulating spatiality in the face of the renewed influence of positivism. As suggested by Pagden, it seems that, "as we move into a new century with its own share of conflicts ... the 
fascination with ... Post-modernism is fading. In its place a new scienticism is on the rise" (2005:17). The warning is not about the escalating scientific and technological advances which are to be celebrated. It is rather about the over-emphasis on rationality and objectivity, and the over-confidence in the power of Reason to control time and space. For planning this is particularly alarming given its depth of affiliation with positivism, as reflected in Friedmann's (1993:482) remark that, "The conventional concept of planning is so deeply linked to the Euclidian mode that it is tempting to argue that if traditional model has to go, then the very idea of planning must be abandoned".

This indicates the enormity of the challenge for planning discipline and profession to embrace the interpretive approach to spatial thinking. Translating a new relational understanding of space and time into the realm of planning practice requires a 'paradigm' leap with implications that are more far-reaching than the 1960s' introduction of systems theory which changed planning from a design-based to a social science-based activity. There are some encouraging signs, as pointed out earlier, but for a shift to happen a more concerted action by planning academics and practitioners is needed.

\section{Acknowledgment}

This paper draws on the contributions to the edited book: Davoudi, S. and Strange, I. (eds) Conceptions of space and place in strategic spatial planning, London: Routledge. My thanks to: Nick Bailey, Gordon Dabinett, Neil Harris, Greg Lloyd, Michael Murray, Graeme Purves, Huw Thomas, Ian Strange, and Jim Walsh for their contributions to the book which in turn provided this paper with the insights into 
contemporary plan making practices. I would also like to thank the anonymous referees for their constructive comments on an earlier version of the paper.

\section{References}

Abercrombie, P. (1933) Town and Country Planning, London: Thornton: Butterworth Agnew, J. (2005) Space: Place, in: Cloke, P. and Johnson, R. (eds), Spaces of Geographical Thought, London: Sage

Allmendinger, P. (2002) Planning Theory, Basingstoke: Palgrave.

Allmendinger, P. and Haughton, G., (2009) Soft spaces, fuzzy boundaries, and metagovernance: the new spatial planning in the Themes Gateway, Environment and Planning A, 41:617-633

Amin A. and Thrift N. (1995) 'Globalisation, 'institutional thickness' and the local economy', in P. Healey, S. Cameron, S. Davoudi, S. Graham, A. Madanipour (eds), Managing Cities, Chichester: John Wiley, 91-108

Audi, R. (1996) The Cambridge Dictionary of Philosophy, Cambridge Press, Cambridge

Barnes, T. (2001) 'Retheorizing economic geography: from the Quantitative Revolution to the Cultural Turn', Annals, Association of American Geographers $91: 546-565$.

Barnet (2009) Characterisation Study of London Borough of Barnet, Draft Final Report, Section I: Introduction, Barnet London Borough

Baumann, Z. (1995) Searching for a centre that holds, in: M. Featherstone, S. Lash and R. Robertson (eds) Global medernities, London: Sage: 140-154

BBR (Federal Office for Building and Regional Planning) (2001), Spatial Development and Spatial Planning in Germany, BBR, Berlin, 15 
Beauregard, P. (2005) Planning and the network city: Discursive correspondences, in Albrechts, L. and Mandelbaum, S (eds.) The Network Society: A new context for planning, London: Routledge, 24-34

Brenner, N. (2000) The urban question: Reflections on Henri Lefebvre, Urban Theory and the politics of scale, International Journal of Urban and Regional Research, $24(2): 361-378$

Cabinet Office (1999a) Modernising Government, Cm 4310, London: Stationary Office

Cabinet Office (1999b) Professional policy making for the 21st Century, London: Cabinet Office.

Charter of Athens (1933) http://www.planum.net/archive/charter.htm; accessed $1 / 9 / 2010$

Davoudi, S. (2006) Evidence-based Planning: Rhetoric and reality, DISP, 165(2)1425

Davoudi, S. (2012f) Climate risk and security: new meanings of the 'environment' in English planning system, European Planning Studies, forthcoming

Davoudi, S. and Madanipour, A. (2012f) The Charters of Athens and two visions of utopia: functional and connected, Built Environment, forthcoming

Davoudi, S. and Strange, I. (2009) Space and place in the twentieth century planning: An analytical framework and an historical review, in S. Davoudi \& I. Strange (eds) Conceptions of Space \& Place in Strategic Spatial Planning, London: Routledge 7-42 DCLG (the Department of Communities and Local Government) (2007) Using evidence in spatial planning, London: DCLG 
Dear, M. (1995) 'Prolegomena to a post-modern urbanism', in P. Healey, S.J. Cameron, S. Davoudi, A. Graham, A. Madanipour (eds) Managing Cities, the new urban context Chichester: John Wiley, 27-44.

Doxiadis, C. (1968) Ekistics, London: Hutchinson

Duhr, S. (2007) The visual language of spatial planning, London: Routledge Ellias, N. (1992) Time: an essay, Oxford: Blackwell

ESDP (European spatial development perspective): Towards a balanced and sustainable development of the territory of the European Union, (1999) Luxembourg: Office for the Official Publications of the European Communities.

Faludi, A. (1973) Planning Theory, Oxford: Pergamon

Fischler, R. (1995) Strategy and history in professional practice: Planning as world making, in H. Ligget and D.C Perry (eds), Spatial Practices, London: Sage 13-59

Friedmann, J. (1993) 'Toward a non-Euclidean mode of planning', Journal of the American Planning Association, 59 (4): 482-485

Hagen, J.E. (2010) Branding, bonding, bringing about... The performance of landscape concepts in spatial planning, Wageningen: Wageningen University

Haggett, P. (1965) Locational Analysis in Human Geography, London: Edward Arnold

Hall, P. (2002) Cities of Tomorrow, $3^{\text {rd }}$ edn, Oxford: Blackwell.

Harley J.B. (1992) Deconstructing the map, in T.J. Barnes and S.J. Duncan (eds) Writing worlds: discourse, text and metaphor, London: Routledge, 231-247

Harley, J.B. (1988) Maps, knowledge and power, in D. Cosgrove and S. Daniel (eds) Iconography of landscape: essays on the symbolic representation, design and use of past environment, Cambridge: Cambridge University Press, 277-312

Harvey, D. (1989) The Condition of Post-modernity, Oxford: Blackwell. 
Harvey, D. (1996) Justice, Nature and Geography of Difference, Oxford: Blackwell Healey, P. (1997) Collaborative planning: shaping places in fragmented societies, London: Macmillan Press.

Healey, P. (2007) Urban Complexity and Spatial Strategies, Towards a relational planning for our times, London: Routledge.

Hoch, C., (1994) What planners do: Power, politics, and persuasion. Chicago, IL: Planners Press

Hollis, M. (2003) The Philosophy of Social Science: An introduction, Cambridge University Press: Cambridge

Howard, E. (1902) Garden Cities of To-morrow, London: Swan Sonnenschein Hubbard, P., Kitchin, R. and Valentine, G, (2004) 'Editors' introduction' in: P. Hubbard, R. Kitchin, and G. Valentine (eds) Key Thinkers on Space and Place, London: Sage

Innes, J. (1996) Planning through consensus building, a new view of the comprehensive planning ideal, American Planning Association Journal 62(4): 460472.

Jacobs, J. (1961) The Death and Life of Great American Cities, Harmondsworth: Penguin (1964 end)

Jensen, O. and Richardson, T. (2004) Making of European Space: Mobility, power and territorial identity, London: Routledge

Joyce, P (2003) The Rule of Freedom: Liberalism and the Modern City, London: Verso

Latour, B. (1993) We have never been modern (translated by C. Porter) Weatsheaf: USA 
Latour, B. (2005) From realpolitike to dingpolitiK, or how to makes things public, http://www.bruno-latour.fr/expositions/96-MTP-DING.pdf accessed 15/9/ 2010

Le Corbusier (1929) The City of Tomorrow and its Planning, London: John Podher (translated by F. Etchelle from L'Urbanisme, 1924, Paris: Edition Cres).

Le Corbusier (1933) La Ville Radieuse, Paris: Freal et Cie (English translation by P. Knight, E. Levieux and D. Coltman, published as The Radiant City, London: Faber \& Faber, 1967)

Leccardie, C. (2008) New biographies in the 'risk society'? About future and planning, the $21^{\text {st }}$ Century Society, the Journal of the Academy of Social Sciences, 3(2) $119-129$

Lefebvre, H. (1991) The Production of Space, Oxford: Blackwell (translated from the original edition, 1974, by N. Donaldson-Smith).

Lindblom, C.E (1959) 'The science of 'muddling through' Public Administration Review, 19:79-88.

London Plan: Spatial development strategy for Greater London (2004) London: Greater London Authority

Luhmann, N. (1982) The future cannot begin: temporal structures in modern society, in: N. Luhmann (ed) The differentiation of society, New York: Columbia University Press: 271-289

Madanipour, A. (1995) Reading the city, in: P. Healey et al (eds) Managing Cities: the new urban context, John Wiley, London, 21-26.

Magee, B (1973) Popper, Glasgow: Collins/Fontana

Massey, D. (2005) For Space, London: Sage.

Murdoch, J. (2006) Post-structuralist geography, Sage, London 
Murray, M. (2009) Building consensus in contested spaces and places: The Regional Development Strategy for Northern Ireland, in S. Davoudi \& I. Strange (eds) Conceptions of Space \&Place in Strategic Spatial Planning, London: Routledge 125147

Nadin, V. (2007) The emergence of the spatial planning approach in England, Planning Practice and Research, 22(1): 43-62

National Planning Framework for Scotland (2004) Edinburgh: Scottish Executive.

ODPM (2004b) The Planning Response to Climate Change: Advice on better practice, London, ODPM.

ODPM (Office of the Deputy Prime Minister) (2004a) Planning Policy Statement 12: Local Development Frameworks, London: ODPM

Osborne, T. and Rose, N. (1999) 'Spatial phenomenotechnics: making space with Charles Booth and Patrick Geddes', Environment and Planning D: Society and Space, $22: 209-28$

Pagden A, (2005) What sparks intellectual movements? The Times Higher Education Supplement, 29 April, 16-17

Peattie, L. (1987) Planning Ciudad Guayana, Ann Arbor: University of Michigan Press

Planning (2009) Centre extends science of planning, 19 June, 23

Regional Development Strategy for Northern Ireland 2025: Shaping Our Future

(2001) Belfast: Department for Regional Development.

Sandercock, L. (2003) Out of the closet: the importance of stories and storytelling in planning practice, Planning Theory and Practice, 4(1) 11-28

Schumaker, P.D. (1978) The quest for control: A critique of the rational-central-rule approach in public affairs, The Journal of Politics, 40(1) 239-242 
Scott, J. (1998) Seeing like a state: How certain schemes to improve human conditions have failed, New Haven CT: Yale University Press

Scruton, R. (1996) Modern Philosophy: An introduction and survey, London: Mandarin.

Soja, E. (1989) Postmodern Geographies: The reassertion of space in critical social theory, London: Verso.

Smith, A.F.M., 1996, Mad cows and ecstasy: chance and choice in an evidence-based society, Journal of the Royal Statistical Society A, Vol. 159(3): 367-383

Taylor, N. (1998) Urban Planning Theory since 1945, London: Sage

Taylor, P. (2005) Time: from hegemonic change to everyday life, in S. Holloway, S.

Rice and G. Valentine, Key concepts in Geography, London: Sage, 151-164

Unger, R. 2007, The self awakened: Pragmatism unbound, Boston: Harvard University Press

Wales Spatial Plan: People, Places, Futures (2004) Cardiff: Welsh Assembly Government

Watson, V. (2003) 'Conflicting rationalities: implications for planning theory and practice', Planning Theory and Practice 4(4): 395-407

Weiss C. H. (1975) Evaluation research in the political context, in: E. S. Struening and M. Guttentag (eds) Handbook of Evaluation Research, Volume 1, London: Sage, $13-25$

Yorkshire and Humber Plan (2006) Wakefield: Yorkshire and Humber Assembly Young, K.; Ashby D.; Boaz, A.; Grayson, L. (2002): Social science and the evidencebased policy movement. Social Policy and Society, 1(3): 215-224

\footnotetext{
${ }^{1}$ Based on Francis Bacon's first way of discovering truth
} 
${ }^{2}$ From the Greek word hermeneus, an interpreter

${ }^{3}$ This was the sub-title of the Ebenezer Howard's book as published in 1898. It was later republished under the most commonly known title of: Garden Cities of Tomorrow (Howard 1902)

${ }^{4}$ See for example Plymouth Local Development Framework website http://www.pas.gov.uk/pas/core/page.do?pageId=110212\#contents-1 , accessed $1 / 9 / 2010$

${ }^{5}$ This was developed by Norbert Wienner in 1948

${ }^{6}$ Or triple dialectic, meaning a three way interactions between these spaces

${ }^{7}$ For the distinction between the instrumental and the enlightenment models of evidence-policy interface see Davoudi (2006)

${ }^{8}$ Through the Planning and Compulsory Purchase Act, 2004 